\title{
Response to an Earthquake in Bangladesh: Experiences and Lesson Learnt
}

\author{
Animesh Biswass,2*, Saidur Rahman Mashreky², Koustuv Dalal'3, Toity Deave ${ }^{4}$ \\ ${ }^{1}$ Department of Public Health Science, Örebro University, Sweden \\ ${ }^{2}$ Centre for Injury Prevention and Research, Bangladesh (CIPRB), Dhaka, Bangladesh \\ ${ }^{3}$ Centre for Injury Prevention and Safety Promotion, School of Health and Medical Sciences, Örebro University, \\ Sweden \\ ${ }^{4}$ Centre for Child \& Adolescent Health, University of the West of England, Bristol, UK \\ Email: *animesh.biswas@oru.se, ani72001@gmail.com
}

Received 4 November 2015; accepted 16 December 2015; published 30 December 2015

Copyright (C) 2016 by authors and Scientific Research Publishing Inc.

This work is licensed under the Creative Commons Attribution International License (CC BY). http://creativecommons.org/licenses/by/4.0/

(c) (i) Open Access

\section{Abstract}

A powerful earthquake occurred in Nepal on 25th April 2015 where the highest measure of the tremor was 7.9 on the Richter scale with a minimum of 6.6. The death toll was around 3000 and thousands were injured in the devastation of the disaster. The earthquake and subsequent earth tremors were also felt in other South East Asian countries including Bangladesh, India and China. Bangladesh was jolted twice by tremors and, although the tremor was not as severe, it was reported to be between 4 and 5 on the Richter scale. Aftershocks over the next few days were also experienced and these ranged around 5 on the Richter scale. In Bangladesh, six lives were lost, and more than 200 people were injured and were taken to hospital. There were also many buildings that collapsed in the mega city Dhaka and its surrounding areas. This study describes the country's response to the earthquake. This experience and the lessons learnt highlight the importance for national earthquake-proof building regulations and systems to lessen the damage and devastation of any future earthquake.

\section{Keywords}

Component, Formatting, Style, Styling

\section{Introduction}

Bangladesh is the world's eighth highest populated country, around 152 million; according to the United Na-

${ }^{*}$ Corresponding author.

How to cite this paper: Biswas, A., Mashreky, S.R., Dalal, K. and Deave, T. (2016) Response to an Earthquake in Bangladesh: Experiences and Lesson Learnt. Open Journal of Earthquake Research, 5, 1-6. http://dx.doi.org/10.4236/ojer.2016.51001 
tions it has $2.16 \%$ of the total world population [1]. The capital, Dhaka, is now the eleventh largest mega city with a population of 17.91 million, and it is predicted to be the sixth largest city in 2030 with a population 27 million [2] [3]. It is estimated that $28 \%$ of the population is poor and approximately 3.4 million people lives in slums [3].

Dhaka is growing rapidly but urbanization is not planned properly. In the last couple of decades, thousands of multi-story buildings have been built without any open spaces and have encroached on the streets and roadways. In addition, most of the natural water reservoirs, such as ponds and ditches, have been covered over with buildings. In many instances, building regulations have not been properly supervised. Furthermore, there are many industries, including garment factories that are located within the capital. There are also buildings in the city that are poorly built, partly constructed with concrete, bamboo or tin and found in high density slum areas.

Dhaka is in a high risk earthquake area, and Bangladesh lies in a seismically active zone making it extremely vulnerable to major earthquakes [4]. Two major fault lines run through Bangladesh, one $144 \mathrm{~km}$ and the other $370 \mathrm{~km}$ from Dhaka. Bangladesh has had several fairly mild earthquakes in the last two decades [5] and two major ones in the past 100 years [4]. Most of the deadliest earthquakes have happened in the Asian belt in the past 30 years and thousands of lives have been lost and countries damaged, especially in Iran, Pakistan, China, Indonesia, Japan, Haiti and Turkey [6] [7]. At present, due to the recent disaster in Nepal, Bangladesh is highly susceptible to the risk of an earthquake. The present country context shows that, due to the unplanned developments in densely-populated, urban Dhaka, there is little evidence of any response strategy that might militate against an earthquake that would be likely to cause extensive damage and significant loss of life [5]. In this paper we describe the impact of the earthquake on Dhaka, the importance of initiating programmes to minimize the impact of any further earthquake.

\section{Methods}

The most popular Bangladeshi daily online version of six English newspapers was reviewed to explore the responses in Bangladesh after a mild earthquake which occurred in Bangladesh on 25th April, 2015. We did not review Bengali version of newspaper due to the time needed for translation from Bengali to English. Moreover, popular daily English e-version newspapers are available online and can be easily read by readers worldwide. The data collected were analyzed manually using content analysis. Categories were established and themes were developed from these categories [8] [9].

\section{Results}

\subsection{What Happened}

The earthquake lasted just over 12 hours and measured 7.8 magnitudes on the Richter scale in the epicenter at Pokhra in Nepal, 745 kilometers away from Dhaka. Dhaka recorded an earthquake between 4 and 5 on the Richter scale. Another strong tremor was felt after the major quake 15 minutes and hours later. Subsequently, another two aftershocks occurred in the next two days and each lasted for a few seconds.

\subsection{Impact in Bangladesh}

\subsubsection{Six Lives Lost}

According to several newspapers, during the earthquake, there were six deaths in four districts of Bangladesh. Four of these died due to cardiac arrest and another one died from a mud wall collapsing on them. In Patna district, one woman aged 67 died due to cardiac arrest while she was hurrying out of a building during the earthquake. Another woman also died when she was at a meeting at school and felt sick during the tremor. She had a cardiac arrest after that and died. In Tangail district, another woman panicked and fainted during the tremor. She was taken to hospital but was declared dead. In Nilphamari district, an older man died in panic when the Villagers ran for cover during the earthquake. In Bogra district, a woman was killed as a mud-wall collapsed on her during the earthquake. Another report mentioned that one patient admitted to Dhaka medical college hospital jumped from the five storey building due to panic and died [10]-[13].

\subsubsection{Injured over 200 People, Majority of Them Were Women}

Newspapers reported that more than 200 people were injured during the earthquake and some of them suffered 
severe injuries when they tried to exit buildings [14]. In one area/town/city, workers in one of the garment factories made serious attempts to exit from the building quickly; many workers had to break windows and escaped that way. Around 100 workers were injured and among them at least fifty were sent to the nearby hospital, of whom 20 were in a critical condition [13] [15]. Similarly, in some other garment factories in the Dhaka division, during the evacuation more than 100 people were injured. At one school, when exiting a two-storey school building at least 18 school children and one teacher were injured [12]. In total, 277 people were injured and 50 were taken to hospital.

\subsubsection{Panic and Illness}

At one high school, students panicked when their school building started shaking. All of them tried to exit the building, at least 12 students felt frightened during the earthquake [16]. Thousands of people rushed away from their homes, offices, work places into the road or open places. One private television channel was live at the time of the earthquake and was interviewing a national singer. The guest and presenters panicked and the singer rushed off the set [17].

\subsubsection{Buildings Titled and Cracked}

In Dhaka, two high rise buildings tilted and cracks have developed since the earthquake [18]. A commercial complex building in south Dhaka leaned under the impact of the tremor [19]. In old Dhaka city, a building tilted to one side but no causalities were reported [20]. According to the fire service and civil defense department around the country about 18 buildings tilted and some others developed cracks [18].

\section{Discussions}

Bangladesh experienced a medium-sized earthquake at the same time as the devastating earthquake in Nepal on 25 April 2015. Several news sources reported six died with two hundred injured, many of whom were admitted to hospital. These were reported to be due to the exiting of multi-storey buildings in a hurry while people were working. Those who were injured were mainly female - they were working in the garment factories. School children were also injured and developed illness. One study looked at the impact of the Haiti earthquake highlighted the injury burden due to earthquake disaster. Overall earthquake injury rate was estimated at 40.2/1000 (CI: 35.6 - 45.3) [21]. Very recently on October 2015, a major earthquake in remote Afghanistan and in Pakistan killed 363 people and injured another thousands of people. In one of the worst accident, at least 12 girls were killed in a rush to escape from the building [22]-[24].

The response of people in Bangladesh to the earthquake indicates that there is a lack of education and preparation about what to do if such an event occurs or how to be safe during an earthquake (Figure 1). One newspaper mentioned that a lack of perception and knowledge were the main reasons that triggered panic. It also highlighted the fact that people came out of high-rise buildings using the stairs during the shaking of the earthquake. This is incorrect, instead they should find a safe corner of a room or building [25] [26].

Our results show that many buildings tilted and cracked during and after the earthquake. The capital city, Dhaka, is very densely populated and is undergoing rapid urbanization. Dhaka is both susceptible to earthquakes but also very vulnerable to substantial building and infrastructure damage, which would leave its large population exposed to potentially more devastating conditions than ever before. There needs to focus immediately on earthquake-proofing buildings and also put in place other technologies such as those employed in other countries like Japan. After the Tsunami disaster, one study mentioned how they had proposed to reconstruction of seawall for future disaster mitigation that could affect coastal communities [27]. Another study in Japan mentioned

Key lessons learnt from $25^{\text {th }}$ April 2015 earthquake in Bangladesh:

- Lack of knowledge and information about what to do.

- Lack of skills on acting safely during an earthquake.

- People panicked.

- Tilting and cracked buildings represent weaknesses in the construction of buildings.

Figure 1. Key lesson learnt in earthquake, Bangladesh. 
to focus on preventing the transmission of infectious diseases among evacuees [28]. Other study in Japan also focused on constructing a system for triage to respond to emergency patients from the initial phase after the Tsunami disaster in 2011 [29].

The newspaper also stressed that a regular survey should be undertaken to audit integrity of older buildings, major public highways and bridges to identify hidden vulnerabilities and prevent future damage [30]. Recently after the Pakistan earthquake disaster, the survey report presented that $99.9 \%$ building in the Rawalpindi city are not earthquake proof and also did not have ability to resist in major earthquake [31]. There was an emphasis on the importance of a standard building codes and rules that were adhered to and the requirement that these should be properly enforced. This would minimize risks and also facilitate the removal of vulnerable buildings [32]. News sources illustrated Dhaka as ranking among the 20 cities most vulnerable to earthquake in the world and stressed that 112 years had already elapsed since a heavy tremor from the Dawki Fault had hit the region, so it was likely that another one was due. One source also described that a 7.6 magnitude earthquake recorded in 1918 in Sreemangal upazila of Moulvibazar district is about 180 kilometers away from capital Dhaka. At present, because of its location in a tectonically active area, it has the high possibility of a substantial earthquake happening at any time [33].

A study predicted that around 78,323 buildings would be completely destroyed if an earthquake of the magnitude of 6 on the Richter scale shook Dhaka. A major earthquake of 7.5 on the Richter scale might kill about 88,000 people, demolish 72,000 buildings and damage 86,000 others in the capital. If an earthquake of an 8.5 magnitude hit the region, around 238,164 buildings would be completely destroyed across the country and economic loss due to damage of structures would be between US\$650 million and US\$1075 million just in the capital Dhaka [34] [35]. Another newspaper article stated that there needs to be huge awareness rising of earthquake preparedness and to take actions. The public can be made aware of earthquake survival through television programmes, newspapers, advertising hoardings, etc. A large scale campaign that includes earthquake safety demonstration is also needed to help manage such a disaster. The article also mentioned the need for regular training programmes for different services, agencies and volunteers for emergency rescue, for example police, army, fire service [32].

In addition to educating the public, an appropriate gas leakage management system, power supply control, firefighting, alternative power generation, wireless communication system, heavy equipment for removing debris and emergency medical facilities are needed to help deal with the aftermath of an earthquake [32] [35]. Under the Comprehensive Disaster Management Programme (CDMP) to strengthen capacity to face disaster, the government decided to train 62,000 community volunteers to carry out rescue operation immediately following any disasters, including earthquake, yet to date 8000 - 9000 volunteers have been registered [5] [27].

When one understands the disturbing situation in Bangladesh, especially the potential impact on the mega city, Dhaka, it is clear that there is an immediate need to set in place a comprehensive plan that would help to alleviate the damage and devastation of any future earthquake. Effective and time limited planning regulations are required, together with its implementation. This should be implemented in the immediate future in order to save thousands of live in Dhaka. The experiences and lessons learnt from the earthquake on 25th April 2015 in Bangladesh should provide sufficient evidence for the planners to focus on the above initiatives in the immediate future.

\section{Conflict of Interests}

The authors declare no conflicts of interest.

\section{References}

[1] (2015) Top 10 Populated Countries in the World. 26 August 2015. http://www.whichcountry.co/top10populatedcountriesintheworld/

[2] Classifieds, N., Opinion, B., Blog, S., Media, M., Streatfield, P.K., Urbanisation, P., et al. (2015) Dhaka Will Be 6th Largest Mega City in 2030: Scientist. 10-13.

[3] Devarajan, S. (2015) World Population Day. July 11 (South Asia Urban Growth) Analysis on Population Growth in South Asia. Example of Population Explosion: Dhaka Mega-City. South Asia World Population, 27-28.

[4] Paul, B.K. and Bhuiyan, R.H. (2010) Urban Earthquake Hazard: Perceived Seismic Risk and Preparedness in Dhaka City, Bangladesh. Disasters, 34, 337-359. http://dx.doi.org/10.1111/j.1467-7717.2009.01132.x 
[5] Cash, R.A., Halder, S.R., Husain, M., Islam, M.S., Mallick, F.H., May, M.A., et al. (2013) Reducing the Health Effect of Natural Hazards in Bangladesh. The Lancet, 382, 2094-2103. http://dx.doi.org/10.1016/S0140-6736(13)61948-0

[6] Motamedi, M.H.K., Sagafinia, M., Ebrahimi, A., Shams, E. and Motamedi, M.K. (2012) Major Earthquakes of the Past Decade (2000-2010): A Comparative Review of Various Aspects of Management. Trauma Monthly, 17, $219-229$. http://dx.doi.org/10.5812/traumamon.4519

[7] (2015) Deadliest Quakes of 30 Years. The Independent, 26 April 2015. http://www.theindependentbd.com/index.php?option=com_content\&view=article\&id $=256$

[8] Morgan, D. (1993) Qualitative Content Analysis: A Guide to Paths Not Taken. Qualitative Health Research, 3, 112 121. http://dx.doi.org/10.1177/104973239300300107

[9] Pope, C., Ziebland, S. and Mays, N. (2000) Analyzing Qualitative Data. In: Pope, C. and Mays, N., Eds., Qualitative Research in Health Care, BMJ Books, London, 75-88.

[10] (2015) 6 Lives Lost in B'desh Many Bldgs Crack. The New Nation, 26 April 2015. http://thedailynewnation.com/news/50948/6-lives-lost-in-bdesh-many-bldgs-crack.html

[11] (2015) Three Women Die as Earthquake Hits Bangladesh. Dhaka Tribune, 26 April 2015.

[12] (2015) 3 Die in Bangladesh during Evacuation after 7.9 Nepal Earthquake. The Daily Star, 26 April 2015. http://www.thedailystar.net/country/major-earthquake-shakes-country-79234

[13] (2015) 3 Killed in Panic, Buildings Tilt in Bangladesh. Tribune, 25 April 2015. http://www.observerbd.com/2015/04/25/85540.php

[14] (2015) Shocks Spark Panic. The Daily Star, 26 April 2015. http://www.thedailystar.net/frontpage/shocks-spark-panic-79293

[15] (2015) 1 RMG Worker Killed, Many Others Injured during Quake. Daily Sun, 25 April 2015. http://www.daily-sun.com/online/city/2015/04/25/10529

[16] (2015) 12 Students Fell Sick during Earthquake in Kushtia. The Daily Observer, 25 April 2015. http://www.observerbd.com/2015/04/25/85530.php

[17] (2015) Earthquake: Live TV Show Participants Taken Aback. The Daily Star, 25 April 2015. http://www.thedailystar.net/online/earthquake-live-tv-show-participants-taken-aback-79244

[18] (2015) Earthquake Jolts Country, 3 Killed, 100 Injured. BSS, 25 April 2015. http://bssnews.net $/$ newsDetails.php?cat $=0 \& \mathrm{id}=488056 \&$ date $=2015-04-25$

[19] (2015) Earthquake Jolts Country Twice. The Daily Observer, 25 April 2015. http://www.observerbd.com/2015/04/25/85523.php

[20] (2015) Storey Building Tilts in Old Dhaka. Bdnews24.com, 25 April 2015. http://bdnews24.com/bangladesh/2015/04/25/6-storey-building-tilts-in-old-dhaka-after-

[21] Doocy, S., Jacquet, G., Cherewick, M. and Kirsch, T.D. (2013) The Injury Burden of the 2010 Haiti Earthquake: A Stratified Cluster Survey. Injury, 44, 842-847. http://dx.doi.org/10.1016/j.injury.2013.01.035

[22] (2015) Big Quake in Afghanistan and Pakistan Kills over 200. Reuters, November 2015. http://uk.reuters.com/article/uk-earthquake-afghanistan-idUKKCNOSK0WQ20151026

[23] (2015) Afghanistan-Pakistan Earthquake Leaves Hundreds Dead. BBC News, November 2015. http://www.bbc.com/news/world-asia-34636269

[24] (2015) Aftershocks Felt in Peshawar Claim Three More Lives. Pakistan Today, 2 November 2015. http://www.pakistantoday.com.pk/tag/earthquake/

[25] (2015) Lack of Knowledge Triggers Panic. The Independent, 26 April 2015. http://www.theindependentbd.com/index.php?option=com content $\& v i e w=a r t i c l e \& i d=256$

[26] (2015) What Should I Do before, during, and after an Earthquake? 22 November 2015. http://www.geo.mtu.edu/UPSeis/bda.html

[27] Koshimura, S. and Shuto, N. (2015) Response to the 2011 Great East Japan Earthquake and Tsunami Disaster. Philosophical Transaction. Series A, Mathematical, Physical, and Engineering Sciences, 373(2053).

[28] Hatta, M. and Kaku, M. (2013) Cooperation and Support Activities of Infection Control after the Great East Japan Earthquake. Rinsho Byori, 61, 1160-1165.

[29] Fukunaga, H. and Kumakawa, H. (2014) Disaster Management at Soma General Hospital in Response to the Great East Japan Earthquake. Japan Medical Association Journal, 57, 331-334.

[30] (2015) No Margin for Error in Building Safety. Dhaka Tribune, 26 April 2015. http://www.dhakatribune.com/editorial/2015/apr/26/no-margin-error-building-safety 
[31] (2015) 99.9 \% Buildings in Rawalpindi Not Quake Proof: Survey. Pakistan Today, 2 November 2015. http://www.pakistantoday.com.pk/2015/11/02/national/99-9-buildings-in-rawalpindi-not-quake-proof-survey/

[32] Ferdousi, S. and Rahman, T. (2010) Earthquake in Bangladesh: How Much We Are Prepared to Face It? Bangladesh Journal of Pathology, 25, 1-2.

[33] Rahman, M.M., Paul, S.K. and Biswas, K. (2011) Earthquake and Dhaka City-An Approach to Manage the Impact. Journal of Science Foundation, 9, 65-75.

[34] (2015) Dhaka Most Vulnerable. The New Nation, 26 April 2015. http://thedailynewnation.com/news/50958/dhaka-most-vulnerable.html

[35] Sultana, S., Rahman, U. and Saika, U. (2013) Earthquake Cause Susceptibility and Risk Mitigation in Bangladesh. ARPN Journal of Earth Sciences, 2, 70-80. 